\title{
Cicatriz aberta ou pápina virada? Lembrar e esquecer o golpe de 1964 Quarenta anos depois
}

Benito Bisso Schmidt ${ }^{*}$

Resumo: Em 2004, o aniversário dos 40 anos do golpe que deu início à ditadura civil-militar no Brasil motivou a irrupção no espaço público de diversos discursos de memória conflitantes relativos àquele acontecimento, com destaque para o discurso governamental, o dos comandantes militares e o das vítimas e seus familiares. O artigo busca, inicialmente, situar este conflito no contexto global de uma "cultura da memória"; a seguir, examina os suportes, agentes, argumentos e imagens específicos de cada um destes discursos, bem como suas estratégias de enquadramento e de silenciamento das lembranças do período; finalmente, discute o papel assumido pelos historiadores nesta "batalha de memórias".

Palavras-chave: Memória. Ditadura civil-militar. Tempo presente.

Em 2004, o aniversário dos 40 anos do golpe que deu início à ditadura civil-militar no Brasil motivou a irrupção no espaço público, especialmente por meio da imprensa, de diversos discursos de memória conflitantes relativos àquele acontecimento. Dentre

* Professor do Departamento e do PPG em História da UFRGS.

Anos 90, Porto Alegre, v. 14, n. 26, p.127-156, dez. 2007 
Cicatriz aberta ou página virada? Lembrar e esquecer o golpe...

eles, destacam-se o discurso governamental, o dos comandantes militares e o das vítimas e seus familiares. Cada um destes discursos procurou estabelecer a forma correta de lembrar (e de esquecer) o golpe, atribuindo-lhe significados variados e situando-o de formas diferenciadas na história brasileira. O elemento detonador desses conflitos foi a discussão a respeito da abertura (ou não) dos arquivos da repressão. O presente artigo analisa essa "batalha de memórias" situando-a, inicialmente, no contexto global de uma cultura da memória, cuja disseminação tornou-se perceptível sobretudo a partir de meados da década de 1970. A seguir, examina os suportes, agentes, argumentos e imagens específicas de cada um desses discursos, bem como suas estratégias de enquadramento e de silenciamento das lembranças do regime ditatorial. ${ }^{2}$ Por fim, discute o papel assumido pelos historiadores nessa batalha.

\section{II}

Já faz mais de uma década que a memória se impôs aos historiadores como um objeto de reflexão incontornável. Na França, a obra coletiva Lieux de mémoire (1984-1993), de Pierre Nora, foi o grande marco dessa "onda de memória" que varreu a historiografia. A perspectiva de Nora recupera, no essencial, a tradição inaugurada pelo sociólogo Maurice Halbwachs, a qual enfatiza o aspecto social e coletivo da memória, bem como sua ancoragem espacial (VALENSI, 1995, p. 1272). Além disso, o historiador também assinala a profunda oposição que separaria a memória da história, contrapondo o caráter afetivo e sacralizante da primeira ao enfoque racional e laicizante da segunda. Contudo, ao menos uma diferença importante distancia as reflexões dos dois autores: Halbwachs sublinha a função positiva - reforçar a coesão social através da adesão espontânea ao grupo - da memória coletiva, que teria sua forma mais acabada na memória nacional; enquanto Nora procura

Anos 90, Porto Alegre, v. 14, n. 26, p.127-156, dez. 2007 
justamente desconstruí-la, evidenciando os atores e processos que intervêm na sua constituição e formalização. Comentando tal mudança de abordagem, diz Pollak (1989, p. 4): "Numa perspectiva construtivista, não se trata mais de lidar com os fatos sociais como coisas, mas de analisar como os fatos sociais se tornam coisas, como e por quem eles são solidificados e dotados de duração e estabilidade". Ainda de acordo com esse autor, "essa predileção atual dos pesquisadores pelos conflitos e disputas em detrimento dos fatores de continuidade e de estabilidade" estaria relacionada às "verdadeiras batalhas da memória" travadas na Europa, sobretudo a partir da metade da década de 1970.

François Hartog (1997, p. 15-6) toma como referência esse mesmo período - a metade dos anos 70 - para analisar o projeto dos Lieux, afirmando que a obra seria um dos sintomas das falhas do regime de historicidade presentista: o presente, que antes parecia bastar-se a si mesmo, mostra-se então inquieto, "em busca de raízes e de identidade", revelando-se "incapaz de preencher a distância, no limite da ruptura, que ele mesmo cavou entre campo de experiência e horizonte de espera". Três palavras resumiriam essa transformação: memória, patrimônio e comemoração, todas apontando em direção a uma outra, que é como se fosse o seu lar: a identidade.

Os debates suscitados pela obra de Nora levantaram uma importante questão: até que ponto suas reflexões e, em especial, a noção de lieux, podem ser aplicadas a outras realidades que não a francesa? $\mathrm{O}$ autor, embora insistindo na "singularidade do caso francês", não deixou de afirmar: "Todos os países têm razões para remontar o passado, mas não todo o passado, nem todas as razões ao mesmo tempo!" (NORA, 1994, p. 190). Porém, sua exemplificação limitava-se a outras regiões da Europa. Lucette Valensi (1995, p. 1272) trouxe ainda um outro questionamento significativo: "Se Pierre Nora fizer escola, os resultados não correm o risco de serem mais repetitivos que cumulativos ou inovadores?"

Anos 90, Porto Alegre, v. 14, n. 26, p.127-156, dez. 2007 
Cicatriz aberta ou página virada? Lembrar e esquecer o golpe...

De qualquer modo, é inegável que uma cultura da memória disseminou-se por diferentes regiões do planeta, adquirindo uma feição globalizada. Porém, como ressalta Andreas Huyssen (2000, p. 16), "[...] embora os discursos de memória possam parecer, de certo modo, um fenômeno global, no seu núcleo eles permanecem ligados às histórias de nações e Estados específicos". Ou seja, se certos temas e categorias - como memória, esquecimento, lugares, amnésia, comemoração, patrimônio, conservação, identidade etc. - circulam transnacionalmente, eles ganham contornos e conteúdos específicos em cada espaço nacional (por exemplo: o Holocausto na Alemanha, a desestalinização nos países do leste europeu, o apartheid na África do Sul, as ditaduras na América Latina).

Assim, para se tentar escapar do risco de "resultados repetitivos" apontado por Valensi, é necessário estabelecer uma adequada articulação entre as dimensões global e nacional dos discursos de memória contemporâneos. Tendo em mente essa preocupação, examina-se agora especificamente o caso brasileiro.

\section{III}

Talvez se possa situar os primeiros sinais mais claros da emergência de uma cultura da memória no Brasil no final da década de 1980, ou seja, um pouco depois da Europa. Nesse momento, duas efemérides mobilizaram debates públicos e a atenção dos historiadores e da mídia: os centenários da abolição da escravidão (1988) e da proclamação da República (1989). Estimulados pela redemocratização política e pela promulgação de uma nova Constituição, intelectuais e movimentos sociais dedicaram-se a reler a história brasileira, buscando desconstruir interpretações consolidadas, como a de que tanto a abolição quanto a instauração da República teriam resultado exclusivamente de decisões da elite política, sem participação popular.

Anos 90, Porto Alegre, v. 14, n. 26, p.127-156, dez. 2007 
Ao longo dos anos 90, verificou-se uma disseminação dos discursos de memória no país. O governo em seus diversos âmbitos, as organizações não-governamentais e a iniciativa privada passaram a investir recursos em projetos ligados à memória, ao patrimônio e a comemorações diversas. Empresas, órgãos públicos, sindicatos, hospitais, escolas e até clubes esportivos manifestaram interesse em preservar seus arquivos, realizar entrevistas, editar livros e edificar memoriais, expondo a seus membros e à sociedade em geral, palavras, imagens, sons e objetos de modo a constituir uma determinada narrativa sobre o seu passado com vistas, obviamente, a consolidar uma imagem presente da instituição enfocada. Tais iniciativas foram pensadas como eficientes estratégias de marketing, dentro de uma lógica de mercantilização e de espetacularização da memória (HUYSSEN, 2000, p. 21).

Caberia perguntar, então, por que justamente naquele momento os discursos de memória passaram a ser um meio eficaz de vender produtos, idéias e imagens? Parece que parte da sociedade brasileira também se deparou com as "falhas do presentismo", ressaltadas por Hartog, deslocando sua perspectiva temporal dos "futuros presentes" característicos da cultura modernista para os "passados presentes" da cultura da memória globalizada (HUYSSEN, 2000).

A "onda de memória" atingiu seu auge às vésperas das comemorações dos 500 anos do "descobrimento" do Brasil. Editoras apressaram-se em lançar inúmeras obras sobre a história do país, com ênfase, é claro, na época colonial. Muitas eram escritas por historiadores, mas o maior best-seller foi uma coleção de três livros "A viagem do descobrimento", "Náufragos, traficantes e degredados" e "Capitães do Brasil" - de autoria do jornalista Eduardo Bueno, o qual, compilando informações da historiografia, elaborou uma narrativa acessível ao público leigo sobre o descobrimento e os primeiros anos da colonização. Aliás, deve-se ressaltar que, em grande medida, os jornalistas protagonizaram essa "redescoberta" da história brasileira, inclusive, como indicarei depois, da história 
Cicatriz aberta ou página virada? Lembrar e esquecer o golpe...

do período militar, fixando algumas das versões mais difundidas a respeito do passado nacional.

No âmbito universitário, realizaram-se seminários, publicaram-se números especiais de revistas acadêmicas e ganharam fôlego as pesquisas sobre a história colonial. Filmes e minisséries da televisão também buscaram retratar o período, normalmente em tom de sátira, tentando identificar as origens do Brasil contemporâneo no momento fundador do descobrimento.

Uma manifestação evidente da espetacularização das comemorações foi a iniciativa, fracassada, de construção de uma réplica da nau Capitânia, da esquadra de Pedro Álvares Cabral, que deveria reproduzir a viagem realizada em 1500. Porém, a embarcação não conseguiu chegar a Porto Seguro, na Bahia. Nessa mesma localidade, uma manifestação de índios, agricultores sem-terra, negros, punks e pobres foi violentamente reprimida pela polícia. Poucos dias antes, um monumento de protesto erguido pelos índios da região foi destruído. De forma muito explícita, travava-se uma disputa por lugares de memória, pelo sentido da comemoração celebração da herança lusa ou denúncia das desigualdades "históricas" da sociedade brasileira? - e, em última instância, pela identidade nacional.

Todas as efemérides até aqui comentadas - abolição da escravatura, proclamação da República e descobrimento do Brasil ganharam destaque nos debates intelectuais e políticos e nos meios de comunicação pelo seu caráter, no mínimo, centenário. Os lutadores das batalhas de memória por elas motivadas não eram, obviamente, testemunhas dos acontecimentos em litígio. Não se tratava, pois, de uma disputa relativa à "visão" - no sentido literal do termo - correta sobre tal ou qual fato, mas sim relacionada a supostas heranças que, enraizadas no passado, conformariam identidades presentes. ${ }^{3}$

Em 2004 foi diferente: os aniversários "cheios" de três acontecimentos da história recente do Brasil colocaram no centro da 
cena pública a figura da testemunha. Refiro-me ao cinqüentenário do suicídio do presidente Getúlio Vargas, aos 40 anos do golpe militar de 1964 e aos 20 anos da campanha das "Diretas Já". A voz dos protagonistas e dos coadjuvantes desses eventos foi insistentemente ouvida e registrada, seja por escrito, seja através de meios audiovisuais. No que se refere aos estudos históricos, consolidouse um traço que Hartog e Revel (2001, p. 20) já haviam detectado na conjuntura historiográfica francesa em 2001: “[...] o primado do 'contemporâneo' ou do 'presente' como categoria dominante [...]".

É importante salientar, porém, que no caso do golpe de 1964 e da ditadura militar, uma abundante e variada memorialística precede em muitos anos a "comemoração" de 2004. ${ }^{4}$ Aliás, o aniversário do início dos "anos de chumbo" serviu, ao mesmo tempo, para reavivar uma já antiga batalha de memória e para a ela acrescentar novas armas e alvos.

IV

Essa batalha teve início ainda em meados dos anos 70, favorecida pelo clima de distensão política "lenta, gradual e segura" do regime militar. Naquele momento, e cada vez mais, memórias antes "subterrâneas" - para usar a expressão de Pollak (1989) - vieram à tona, sobretudo na forma de livros e entrevistas à imprensa, tanto de colaboradores quanto de opositores do regime. Tais obras, de certa forma, deram continuidade à luta política do período (MARTINS FILHO, 2002, p. 178).

Em suas narrativas, os opositores do regime seguiam, normalmente, um desses caminhos: ou faziam uma autocrítica de sua passagem pela luta armada, questionando as diretrizes e estratégias da esquerda tradicional e apostando em outras formas de atuação política (movimento feminista e ecológico, por exemplo), com forte inspiração no espírito libertário de 68; ou exaltavam o heroísmo 
Cicatriz aberta ou página virada? Lembrar e esquecer o golpe...

da resistência dos militantes de esquerda e reafirmavam os ideais revolucionários motivadores de seus combates do passado. Do lado dos militares também houve divisões: alguns assumiram a defesa incondicional das bandeiras que motivaram o golpe, outros denunciaram o desvirtuamento dos projetos originais (CARDOSO, 1997).

Todas essas narrativas procuravam assentar a "verdade dos fatos" em relação aos anos iniciais da ditadura, reivindicando para o seu testemunho o estatuto de "prova" e, em decorrência, demandando a confiança dos leitores na fidedignidade do que era narrado. Afinal, conforme salienta Paul Ricoeur (2000, p. 205), "[..] esta estrutura dialógica do testemunho faz-lhe ressaltar imediatamente a dimensão fiduciária: o testemunho pede para ser acreditado. Ele não se limita a dizer: 'Eu estava', ele acrescenta: 'Creia-me"'.

O caráter de prova dessas memórias mostra-se especialmente problemático principalmente por dois motivos. Primeiro, devido à inacessibilidade até o presente momento de diversos arquivos da repressão, que poderiam confirmar ou pôr em xeque tais lembranças. Segundo, em razão da própria ambigüidade da noção de verdade nas chamadas "escritas de si" (como as autobiografias e as memórias), a qual oscila entre a "verdade factual", objetiva e submetida à prova (científica e/ou jurídica), e a "verdade interior", a sinceridade daquele que rememora (GOMES, 2004, p. 13-4).

Cabe também acrescentar que, ainda na primeira metade dos anos 70, iniciou-se no Brasil a luta dos familiares dos presos, mortos e desaparecidos políticos. Em diferentes regiões do país, foram organizados grupos para exigir do Estado informações a respeito da morte e do desaparecimento de parentes, bem como para denunciar as torturas e as degradantes condições dos cárceres. Essa luta tornou-se ainda mais intensa a partir do final de 1973 e durante todo o ano de 1974, quando não houve vítimas oficiais - todas foram consideradas "desaparecidas" (LISBOA, 2004b, p. 161-2). 
A promulgação da Lei da Anistia proposta pelo governo do general João Figueiredo em 1979 frustrou as expectativas dos opositores do regime. A lei procurava instaurar por decreto uma reconciliação nacional, baseada no esquecimento do passado. Assim, anistiavam-se tanto os presos políticos, os exilados e os clandestinos, quanto os mandantes e os responsáveis por torturas e assassinatos. Suzana Lisboa (2004b, p. 161-2), representante das famílias na Comissão de Mortos e Desaparecidos Políticos do Rio Grande do Sul, expressou esta frustração:

A anistia conquistada trouxe ao país os presos políticos, exilados e clandestinos, mas os mortos e desaparecidos não voltaram sequer na forma de um atestado de óbito. [...] Os torturadores, mandantes e responsáveis pelas torturas e assassinatos não foram condenados, nem sequer julgados ou citados em processos criminais, a maior parte mantendo-se no anonimato até hoje. Por que foram, então, anistiados? Não pelo império da lei, mas através de uma interpretação da lei de que a abertura politica poderia retroceder se houvesse por parte da oposição uma postura revanchista.

Porém, a batalha de memórias aqui examinada não se encerrou por decreto com a anistia e nem mesmo com o final da ditadura e a restauração das liberdades democráticas. Os opositores do regime justificaram a divulgação de suas lembranças por um "dever de memória". Para alguns, esse dever manifesta-se na forma de um chamamento interior, relacionado à impossibilidade de esquecer. Tal é o caso do jornalista e advogado Flávio Tavares, participante da luta armada na década de 60. No seu livro Memórias do esquecimento, ele afirma de maneira poética:

Eu me lembro tanto de tanto ou de tudo que, talvez por isso, tentei esquecer. [...] Sim, minha amada, o que os meus olhos viram às vezes tenho vontade de cegar.

Anos 90, Porto Alegre, v. 14, n. 26, p.127-156, dez. 2007 
Cicatriz aberta ou página virada? Lembrar e esquecer o golpe...

Esquecer? Impossível, pois o que eu vi caiu também sobre mim, e o corpo ou a alma sofridos não podem evitar que a mente esqueça ou que a mente lembre. Sou um demente escravo da mente.

[...] A única solução é não esquecer.

E por não esquecer te conto, minha amada. Como um grito de conto. Ouve e lê (TAVARES, 1999, p. 13).

Diante de tantas lembranças, coloca-se o imperativo de contar. "Escravo da mente", o autor solicita a cumplicidade de uma interlocutora imaginária e de todos nós, seus leitores: ouçam-me, leiam-me e creiam-me!

Outros ex-militantes de esquerda conferem um caráter coletivo aos seus testemunhos pessoais, como fizeram muitos sobreviventes dos campos de concentração nazistas. Segundo eles, rememorar as atrocidades cometidas pela ditadura significa dar vOz àqueles que não puderam contar. Nesse sentido, cito o depoimento de Cecília Coimbra, fundadora do Grupo Tortura Nunca Mais, a uma revista brasileira: "[...] pela minha boca muitas pessoas estão falando, pessoas que não puderam falar, que se desestruturaram [...] Então, acho que a gente tem uma responsabilidade terrível em cima disso. A gente sobreviveu a isso, a gente tem de falar sobre isso" (COIMBRA, 2004, p. 32).

Por fim, de acordo com várias das vítimas do regime, o lembrar tem um sentido "pedagógico": aprender com o passado a fim de evitar, no presente, a repetição de acontecimentos semelhantes (algo próximo da noção de historia magistra vitae). O lema da Comissão de Mortos e Desaparecidos Políticos do Rio Grande do Sul é eloqüente nesse sentido: "Para que não se esqueça. Para que nunca mais aconteça".

Já os militares, de forma praticamente unânime, consideram "revanchista e inoportuna" a atitude daqueles que insistem em falar sobre os "porões" da ditadura. De acordo com eles, tal postura 
viola o próprio princípio da anistia que pressupõe "zerar as contas [...], esquecer" (MARTINS FILHO, 2002, p. 180). Nas palavras de um desses militares, Jarbas Passarinho: “[...] os vencedores pelas armas não pregavam o perdão, que pressupõe arrependimento, mas o esquecimento mútuo, fundamental para a reconciliação, esquecendo as paixões. Ledo engano. Só os vitoriosos esqueceram" (apud MARTINS FILHO, 2002, p. 180-1). ${ }^{5}$

O grande ponto de atrito desses relatos diz respeito à questão da tortura. Nas lembranças dos opositores do regime, a prática de torturas físicas e psicológicas ganha centralidade e, obviamente, um forte caráter de denúncia. Os militares, por seu turno, insistem em dizer que tal prática era episódica e, sobretudo, desconhecida dos escalões superiores; no máximo, afirmam que "houve excesso nos dois lados" (MARTINS FILHO, 2002, p. 191).

Nos últimos anos, a memória das vítimas parece ter vencido a batalha. Hoje, no Brasil, são poucos os que negam a existência da tortura durante o regime militar. Mais ainda, raros são os que se identificam publicamente com a ditadura (inclusive aqueles que notoriamente participaram de seu funcionamento). Na versão divulgada pelos meios de comunicação, prevalece uma imagem: "a sociedade brasileira viveu a ditadura como um pesadelo que é preciso exorcizar [...]” (REIS, 2000, p. 9). Nessa perspectiva, os militantes de esquerda são apresentados como jovens heróicos, rebeldes e generosos, mas também ingênuos e equivocados, apoiadores de um projeto derrotado de antemão. Eles teriam aderido à luta armada em defesa da democracia e em uma reação desesperada à falta de alternativas políticas legais. "Esquece-se", assim, que, em muitos grupos, o projeto da luta armada precede o próprio golpe militar e que a democracia representativa não era um valor muito prezado por boa parte das correntes da esquerda brasileira da época (REIS, 2000, p. 9 e ROLLEMBERG, 2003). Três exemplos dessa "memória enquadrada", termo considerado por Rousso (1985, p. 73) como mais adequado do que memória 
Cicatriz aberta ou página virada? Lembrar e esquecer o golpe...

coletiva, são a minissérie de televisão "Anos Rebeldes" (1992), o filme "O que é isso companheiro?", de Bruno Barreto (1997) baseado no livro de memórias homônimo de Fernando Gabeira (1979) - e a novela "Senhora do Destino" (2004-2005), todos grandes sucessos de público.

Falar de uma memória enquadrada da ditadura militar implica falar de um trabalho de enquadramento, o qual envolve processos de organização das lembranças, dos silêncios e dos esquecimentos; de seleção do que pode ou não ser dito publicamente. Tal operação - e aqui cito novamente Pollak (1989, p. 9-10) - também "[...] deve satisfazer a certas exigências de justificação", ou seja, "[...] o trabalho permanente de reinterpretação do passado é contido por uma exigência de credibilidade que depende da coerência dos discursos sucessivos". No caso em pauta, as memórias das vítimas forçaram, por exemplo, o reconhecimento da existência da tortura. Porém, os meios de comunicação acabaram situando essa prática no interior de uma "guerra suja", alheia ao grosso da sociedade brasileira, entre militares truculentos e jovens rebeldes.

Contra esta interpretação, colocam-se os grupos ligados aos familiares de mortos e desaparecidos políticos e outras entidades defensoras dos direitos humanos. Estas, há muitos anos, denunciam a presença de torturadores em cargos governamentais, a permanência da tortura como forma de interrogatório nas delegacias de polícia e a continuidade do treinamento embrutecedor nas Forças Armadas, e, sobretudo, cobram o estabelecimento da "verdade dos fatos" a respeito dos mortos e desaparecidos: quem os matou? Em quais circunstâncias? Por ordem de quem? Onde estão os corpos? Ou seja, insistem na responsabilidade do governo e da sociedade em relação às vítimas do terror de Estado.

Em 1995, o governo federal assumiu a responsabilidade pela morte dos desaparecidos políticos e garantiu às famílias o direito ao óbito do familiar e posterior indenização. O segundo artigo da referida Lei explicita as suas intenções: "A aplicação das disposi- 
ções dessa Lei e de todos os seus efeitos orientar-se-á pelo princípio de reconciliação e de pacificação nacional, expresso na [...] Lei da Anistia" (BRASIL, 1995 - grifo meu).

Os familiares dos desaparecidos, porém, não se mostraram adeptos desse princípio e, ao investigarem as sevícias sofridas por seus parentes, transmutaram-se em detetives-historiadores, buscando, ao mesmo tempo, provas jurídicas e históricas que possibilitassem a identificação dos culpados e a compreensão do passado recente do país. Segundo Suzana Lisboa (2004b, p. 162-3 - grifo meu):

Aos familiares coube a árdua, extenuante e desesperadora tarefa de buscar, nos poucos documentos a que tiveram acesso, as provas para contestar as versões de suicídios, atropelamentos e tiroteios e por cerca de 130 vezes até o momento, conseguimos comprovar que essas versões foram uma mentira para encobrir as mortes sob tortura. Solitariamente, os familiares têm analisado documentos, laudos periciais e necroscópicos, tentando extrair, com lentes e lupas, as marcas de tortura nos rostos crispados pela morte, assumindo, enfim, o estranho e fundamental papel de reescrever a história de nosso país. As dificuldades advindas desse trabalho são enormes, não só pela sua magnitude e envol-vimento emocional, mas porque os principais arquivos da repressão não foram abertos.

Um decreto do presidente Fernando Henrique Cardoso de 1997 estabeleceu os prazos de 5 anos de sigilo para os documentos reservados, 10 para os confidenciais, 20 para os secretos e 30 para os ultra-secretos. Todos poderiam ser renovados apenas uma vez. No final de seu segundo mandato, por pressão dos militares, o presidente prorrogou esses prazos, estabelecendo 10 anos para os documentos reservados, 20 para os confidenciais, 30 para os secretos e 50 para os ultra-secretos, podendo esse último ser renovado por tempo indefinido. Começava aí um novo lance da batalha de memórias: a luta pela abertura dos arquivos da ditadura. 
Cicatriz aberta ou página virada? Lembrar e esquecer o golpe...

V

A posse do presidente Luiz Inácio Lula da Silva, figura emblemática da oposição ao regime militar em seus anos finais, cujo governo abrigava e abriga em vários cargos do alto escalão ex-participantes da luta armada, prometia novidades aos lutadores dessa batalha. Porém, o novo governante frustrou muitas expectativas (inclusive a dos historiadores) ao não revogar o decreto que definia as regras de sigilo antes mencionadas. Logo ele que, em 1999, quando das comemorações dos 20 anos da Lei da Anistia, havia afirmado: "Só tendo um conhecimento profundo sobre tudo o que se passou nos porões da repressão naqueles anos, o Brasil conseguirá se proteger de verdade contra a repetição de um período tão tenebroso de nossa história" (apud BIZ, 2004, p. 147).

Como apontei antes, as comemorações dos 40 anos do golpe militar em 2004 reativaram essa já longa batalha e a ela acrescentaram novos ingredientes. As memórias que então emergiram no espaço público conferiram significados diversos àquele acontecimento, delineando, ao mesmo tempo, imagens variadas da situação brasileira contemporânea após tantos anos de restabelecimento da democracia.

A mensagem oficial do Exército a respeito da data, escrita pelo general Francisco Roberto de Albuquerque, dirigia-se ao "jovem soldado" e contrapunha duas temporalidades distintas: os "tempos modernos" de "uma República independente e livre, em contínuo aperfeiçoamento, no caminho democrático" e os "difíceis momentos, como aqueles de 31 de março de 1964". Entre elas, estabelecia uma continuidade:

Nossos antepassados viveram, reagiram e enfrentaram, com coragem, otimismo e dignidade, as peculiaridades e os desafios próprios de suas épocas. Às gerações atuais, cabe revitalizar as tradições, praticar e ampliar os sadios valores e

Anos 90, Porto Alegre, v. 14, n. 26, p.127-156, dez. 2007 


\section{Benito Bisso Schmidt}

acrescentar mais glórias. [...] A paz, você sempre a quis, com fervor. Mais que conquistá-la, com toda a sociedade, a constrói e a preserva.

Especificamente em relação ao aniversário do golpe, o general escreveu:

Soldado, livre da visão desarrazoada, considere a importância de viver em uma sociedade cujos filhos não estão divididos pelas paixões ideológicas e não estão expostos às inquietações do passado. Some esforços para realizar, no presente, com um trabalho integrado, o Brasil com que sonhamos.

Veja o 31 de março de 64 como uma página de nossa História, com o coração livre de ressentimentos. Homenageie esse fantástico povo brasileiro, exemplo da gente pacificadora, que conquistou a convivência harmônica e busca, otimista, o bem comum (INFORMEX, 25/03/2004).

O "jovem soldado" deveria, portanto, ancorar-se de maneira firme no presente, imunizar-se das "inquietações do passado" e congelar o regime militar em um momento distante da história, sem vínculo algum com a atualidade. Das gerações anteriores, ele não herdaria ressentimentos, apenas os "valores sadios" de um indefinido "povo brasileiro": a coragem, o otimismo, a dignidade e, sobretudo, o gosto pela paz e pela harmonia.

Com o mesmo tom conciliador e a mesma aposta nos valores positivos do "povo brasileiro", o presidente Lula declarou em 31 de março de 2004: "devemos olhar para 1964 como um episódio histórico encerrado. $\mathrm{O}$ povo brasileiro soube superar o autoritarismo e restabelecer a democracia. Cabe agora aos historiadores fixar a justa memória dos acontecimentos" (FOLHA DE SÃO PAULO, 01/04/2004, p. 14).

Nas palavras do governante, ecoa a memória difundida pelos militares e pelos meios de comunicação a respeito da ditadura 
Cicatriz aberta ou página virada? Lembrar e esquecer o golpe...

militar. Esta teria sido completamente alheia ao "povo brasileiro", portador de profundas convicções democráticas, e, no final, acabaria vencida por ele. "Encerrada", não manteria nenhuma relação com a realidade atual do país. Aos historiadores, caberia a tarefa de "fixar [e este verbo é significativo] a justa memória dos acontecimentos", quer dizer, a "verdade dos fatos", imobilizando-os no passado, bem distantes dos debates políticos do presente.

Assim, no aniversário do golpe, tanto o presidente quanto os militares apostaram no esquecimento como forma de conciliação nacional. Já os grupos de direitos humanos ligados às vítimas da ditadura trataram de sublinhar, ao contrário, as continuidades entre o passado recente e o presente da sociedade brasileira. Na citada entrevista de Cecília Coimbra, podem ser encontrados diversos exemplos desse esforço:

Agora, hoje, neste momento, alguém está sendo torturado no país e a gente finge que não sabe.

Esses caras [os torturadores] têm de ser julgados, eles não podem continuar como estão ainda hoje. Continuam impunes e sendo premiados, inclusive ganhando em dólar no exterior, como adidos militares em embaixadas e consulados. De vez em quando a gente sabe de algum deles (COIMBRA, 2004, p. 32 e 34).

Portanto, de forma geral, verifica-se o embate entre duas perspectivas: uma que busca o esfriamento dos fatos passados e sua fixação na história, como página virada; e outra que, pelos mecanismos próprios da memória, esquenta-os e atualiza-os, como cicatriz aberta. Afinal, de acordo com Antoine Prost (2000, p. 11):

A procura pela memória comporta sempre uma dimensão afetiva: aquilo que se passou, cuja memória deve ser guardada, é seguidamente uma provação, um drama, uma tragédia. As cicatrizes não estão totalmente fechadas e a ferida

Anos 90, Porto Alegre, v. 14, n. 26, p.127-156, dez. 2007 
permanece viva. Evocar então um direito de memória é convidar toda a coletividade a compartilhar uma indignação, uma revolta ou um luto, e a transformá-la em resolução.

Qual a principal resolução demandada pelas vítimas da ditadura em 2004? Depois de conseguirem responsabilizar o Estado pelas mortes e desaparecimentos de seus familiares e de conquistarem indenizações em razão de danos pessoais e profissionais sofridos por motivos políticos, o que mais havia a exigir? $\mathrm{E}$ ainda: como seria possível, depois de tantos anos, convidar "toda" a sociedade brasileira a compartilhar sua indignação, sua revolta e seu luto?

Pode-se dizer que, ao longo de 2004, a batalha de memórias a respeito da ditadura militar brasileira travada entre governo, militares e vítimas passou a ter como eixo central a abertura ou não dos arquivos repressivos. Estes acervos - não só pelos possíveis documentos neles contidos, mas também pelo seu conteúdo simbólico de "segredo" - tornaram-se o principal "lugar de memória" disputado pelos participantes da contenda.

A questão dos arquivos emergiu com força no mês de outubro de 2004, quando um jornal divulgou supostas fotografias de uma das mais famosas vítimas da ditadura: o jornalista Vladimir Herzog. Em 24 de outubro de 1975, agentes dos serviços de inteligência do governo convocaram "Vlado", como Herzog era conhecido, a depor sobre suas ligações com o Partido Comunista. Na manhã seguinte, ele foi espontaneamente ao quartel onde funcionava a polícia política. Seu depoimento transformou-se numa sessão de tortura que o levou à morte. Os serviços de inteligência logo divulgaram a versão de suicídio. Porém, o crime causou comoção na opinião pública. O Sindicato dos Jornalistas convocou um ato ecumênico em São Paulo, reunindo centenas de pessoas, que logo se transmutou em um ato de protesto contra a ditadura. O rabino Henry Sobel recusou-se a enterrá-lo na área do cemitério israelita 
Cicatriz aberta ou página virada? Lembrar e esquecer o golpe...

destinada aos suicidas. Em 1978, a Justiça responsabilizou o Estado pela tortura e morte de Herzog. Em 1996, a Comissão Especial dos Desaparecidos Políticos concluiu que o jornalista havia sido assassinado, e concedeu indenização à família.

A fotografia de Vlado divulgada pelos agentes da repressão - na qual ele aparece enforcado de joelhos - tornou-se um ícone da resistência ao regime militar, constantemente reproduzida na imprensa, em livros (inclusive escolares) e em exposições referentes ao período.

As fotos publicadas pelo jornal Correio Braziliense em 2004 supostamente mostravam Herzog preso, ainda vivo, nu e em situação humilhante. As imagens foram entregues à Comissão de Direitos Humanos da Câmara dos Deputados por um ex-agente do serviço de inteligência do Exército, cabo José Alves Firmino, o qual garantiu que uma grande quantidade de documentos produzidos pela repressão foi preservada e poderia ajudar a esclarecer as mortes de militantes políticos. De acordo com ele, tais papéis estariam em um arquivo subterrâneo na sede do Comando Geral do Exército em Brasília.

A partir daí, emergiu uma controvérsia sobre as fotos. Clarice, esposa de Herzog, confirmou sua autenticidade, mas peritos e membros do governo afirmaram que o homem retratado era o padre canadense Lépold D'Astous, que morou no Brasil nos anos 70 e foi perseguido pelo governo. Este desmentiu o fato e logo em seguida voltou atrás, e admitiu ser ele a pessoa fotografada. Enfim, diante de tantas opiniões contraditórias, as fotos ficaram envoltas num clima de suspeição, o que fragilizou seu estatuto de prova. Serviram, porém, para acirrar o debate a respeito dos arquivos da repressão.

Pouco tempo depois da publicação das imagens, o Exército emitiu uma nota oficial reafirmando a interpretação tradicional da instituição a respeito do golpe militar de 64. Conforme o texto, na época, "as medidas tomadas pelas Forças Legais foram uma legítima 
resposta à violência dos que recusaram o diálogo, optaram pelo radicalismo e pela ilegalidade e tomaram a iniciativa de pegar em armas e desencadear ações criminosas". O texto prossegue: "Quanto às mortes que teriam ocorrido durante as operações, o Ministério da Defesa tem, insistentemente, enfatizado que não há documentos históricos que as comprovem, tendo em vista que os registros operacionais e da atividade de inteligência da época foram destruídos em virtude de determinação legal". Por fim, a nota retoma antigos argumentos utilizados pelos militares nessa já longa batalha de memórias: "O Exército Brasileiro [...] vem demonstrando total identidade com o espírito da Lei da Anistia. [...] Por esse motivo considera os fatos como parte da História do Brasil. [...] Considera ação pequena reavivar revanchismos ou estimular discussões estéreis sobre conjunturas passadas" (ZERO HORA, 19/10/2004, p. 12).

O presidente Lula não gostou do tom da mensagem e exigiu uma retratação do Comandante do Exército, general Francisco Albuquerque, o que resultou numa segunda nota oficial com um pedido de desculpas pela morte de Herzog e o reconhecimento de que o assunto não fora abordado de maneira adequada. Mesmo assim, o Ministro da Defesa, José Viegas, disse à imprensa: "Não tenho nenhuma motivação de ficar revolvendo esses casos do passado. Eles pertencem à história e devem ser analisados por historiadores [...]" (ZERO HORA, 21/10/2004. p. 17). O caso, porém, não se cristalizou no passado, nem ficou restrito ao círculo dos historiadores. Ao contrário, continuou muito presente, gerando mal-estar no governo e nas Forças Armadas, o que acabou motivando a demissão de Viegas do Ministério.

$\mathrm{Na}$ esteira da controvérsia, os grupos de direitos humanos ganharam espaço na mídia, trazendo a público suas reivindicações. O Tortura Nunca Mais, por exemplo, afirmou que pretendia iniciar uma campanha no Brasil e no Exterior pela apuração de casos de tortura policial e de mortes de opositores do regime militar, como 
Cicatriz aberta ou página virada? Lembrar e esquecer o golpe...

a de Herzog. Embora reconhecendo o valor comprobatório - tanto perante a justiça, quanto diante do "tribunal da História" - dos depoimentos das vítimas, tais grupos viram na abertura dos arquivos uma forma de reforçar sua versão do passado, assentando-a em provas materiais. Nesse sentido, Cecília Coimbra afirmou: "É escandaloso, porque a gente tem os depoimentos das pessoas e isso é documento histórico: a gente fala o nome dos torturadores, nenhum deles mostra a cara..." Sobre a importância dos arquivos, ela ressalta:

Mesmo que tenham destruído [alguns documentos do período], acho que são poucos, porque, desde que o grupo Tortura Nunca Mais apareceu, em 1985, a gente fala da questão de ter comprovação das mortes, saber o que aconteceu, que são as perguntas que as Madres da Plaza de Mayo fazem: onde, como, quando, quem? Você tem de saber isso. $\mathrm{Eu}$, inclusive, não estou morta, mas preciso esclarecer algumas coisas da minha prisão. [...] É aquilo mesmo: você só pode esquecer, e superar, se fica sabendo o que aconteceu (COIMBRA, 2004, p. 32 e 34 - grifos meus).

O cantor Nei Lisboa, irmão de Luiz Eurico Tejera Lisboa, morto pela repressão governamental, também cobrou a abertura dos arquivos como um importante suporte à memória das vítimas:

Aos militares e civis que [...] perpetraram [a ditadura militar], o Brasil oferece, respeitosamente, não a mera impunidade, mas a guarda vitalícia da memória nacional entre arquivos, cadáveres, fatos e nomes que jamais lhes foram exigidos. Aquilo que pretendemos nunca mais esquecer, é prudente que antes tenhamos como lembrar (LISBOA, 2004a, p. 145-6).

Acolhendo essas demandas, o deputado Luiz Eduardo Greenhalgh propôs a criação de uma Comissão Nacional da Verdade para esmiuçar os arquivos dos órgãos de segurança, justificando a medida com as seguintes palavras: "Não é possível permanecermos 
com fantasmas pairando sobre a cabeça de todos nós. As fotos divulgadas como sendo do Herzog só trazem uma certeza, de tempos em tempos, novos documentos, novas fotos vão surgir" (O SUL, 23/10/2004, p. 3 - Caderno Reportagem).

Nesta perspectiva, a abertura dos arquivos permitiria afugentar certos fantasmas que atormentam a sociedade brasileira, espectros esses alimentados pelos segredos zelosamente guardados por instituições ligadas à repressão política, em especial as Forças Armadas. A materialidade dos documentos possibilitaria, assim, comprovar os testemunhos das vítimas do terror de Estado, garantindo a sua vitória definitiva na batalha de memórias. Tratase, portanto, conforme assinala Huyssen (2000, p. 16), de “[...] tentativas [...] para criar esferas públicas de memória 'real' contra as políticas do esquecimento, promovidas pelos regimes pós-ditatoriais, seja através de reconciliações nacionais e anistias oficiais, seja através do silêncio repressivo".

Outra, obviamente, é a postura dos indivíduos ligados à ditadura, como o ex-chefe da agência central do antigo Serviço Nacional de Informações, general Newton Cruz: "Eu acho que não se deve falar mais nisso. Vão achar papéis esparsos, se houver alguma coisa ainda, o que conduzirá a coisas erradas e a generalizações. [...] Se aparecer alguma coisa, não vai esclarecer a história, vai confundir a história" (O SUL, 25/10/2004. p. 3 - Caderno Reportagem).

Os meios de comunicação investiram na espetacularização dessa controvérsia. Por exemplo: a Rede Globo veiculou um programa a respeito do assassinato de Vladimir Herzog. Ao longo de quase uma hora, depoimentos de familiares, amigos, colegas de trabalho e representantes da sociedade civil foram editados e intercalados com passagens nas quais atores dramatizavam o episódio. A "ficção" da encenação mesclou-se com a "verdade" dos testemunhos na construção de uma determinada memória sobre os fatos. No final da transmissão, uma voz em off anunciava que 
Cicatriz aberta ou página virada? Lembrar e esquecer o golpe...

os torturadores do jornalista já haviam morrido. A mensagem pareceria ser: trata-se de um caso muito triste, mas definitivamente encerrado no passado. Contudo, nas palavras de alguns dos depoentes, o programa legitimou-se justamente por tornar esse passado presente, na forma de uma narrativa de caráter pedagógico. Por exemplo: "Acho importante a iniciativa de lembrar a história, porque há uma geração no Brasil que não sabe o que aconteceu. Foi um acontecimento histórico, político e de cunho moral para o futuro do nosso país", disse Henry Sobel (CARTA CAPITAL, 15/09/2004, p. 28). Parodiando Revel, Certeau e Julia (1989, p. 49) no seu estudo sobre a cultura popular, o programa celebrou "a beleza do morto": Herzog tornou-se objeto de interesse porque o seu perigo foi eliminado.

O governo federal, por seu turno, portou-se novamente de maneira ambígua em relação aos arquivos. No final de 2004, editou um decreto reduzindo o prazo para a abertura dos documentos oficiais classificados como sigilosos. Porém, através de uma medida provisória abriu uma brecha para que, na prática, fosse mantido o "sigilo eterno" em certos casos imprescindíveis "à segurança da sociedade e do Estado". O decreto também criou a Comissão de Averiguação e Análise de Informações Sigilosas, responsável pela autorização final antes da divulgação dos acervos ao público.

A Comissão reuniu-se pela primeira vez em dezembro de 2004, e requisitou os arquivos das Forças Armadas. A medida incluía todos os documentos produzidos nos 40 anos anteriores e atingia ainda a Agência Brasileira de Inteligência, a Polícia Federal, a Comissão Geral de Investigações e o Conselho de Segurança Nacional. Previu-se, também, a requisição de acervos em poder de particulares. Após a classificação, os documentos deveriam ser enviados ao Arquivo Nacional (FOLHA ONLINE, 15/12/2004). Com essas medidas, os fantasmas do passado parecem ter voltado a assombrar certos indivíduos e grupos sociais pois, nos dias seguintes 
ao encontro da Comissão, a imprensa noticiou várias tentativas de destruição de documentos referentes à repressão governamental pós64 em diversas regiões do país (ver FOLHA ONLINE, 16/12/2004, 17/12/2004 e 26/12/2004).

Noticiou-se também que o presidente Lula autorizou a Secretaria Especial de Direitos Humanos a organizar em Brasília um "arquivo da intolerância", a partir de 2005, reunindo livros, fontes orais e documentos escritos que relatassem mortes, desaparecimentos e torturas no país, tornando-os acessíveis à população. Conforme o jornal Folha de São Paulo, "a medida atenderia a entidades de direitos humanos céticas em relação à forma como o governo federal vem discutindo a abertura de arquivos oficiais" (FOLHA ONLINE, 21/12/2004). Porém, essa iniciativa de "arquivamento do trauma", que poderia compensar, de alguma forma, a ausência de um espaço fúnebre tão necessário para alimentar a memória das vítimas sobreviventes e dos familiares (HUYSSEN, 2000 , p. 20), parece não ter prosperado. Observa-se aqui - ainda nas palavras de Huyssen (2000, p. 33) - "[...] a idéia do arquivo, como um contrapeso ao sempre crescente passo da mudança, um lugar de preservação espacial e temporal". Afinal, "do ponto de vista do arquivo, é claro, o esquecimento é a última das transgressões". Resta saber se esta seria uma forma eficiente de fazer "toda" a sociedade brasileira compartilhar a revolta e o luto inerente a tais lembranças ou se, ao contrário, corre-se o risco da banalização das memórias sobre a ditadura.

Depois de muitas polêmicas, em 21 de dezembro de 2005, um ano depois da primeira reunião da Comissão, o material produzido pelos extintos serviços de informação e segurança nacional, relativo ao período 1964-1990, foi transferido para o Arquivo Nacional. Por ocasião do anúncio da transferência, a ministra-chefe da Casa Civil, Dilma Rousseff, ex-presa política, chorou e, emocionada, disse: "Os documentos estão deixando de ser do serviço de inteligência e, a partir de agora, passam a fazer parte da história do 
Cicatriz aberta ou página virada? Lembrar e esquecer o golpe...

país" (ZERO HORA, 22/12/2005, p. 6). Contudo, as regras referentes aos prazos de sigilo ${ }^{6}$ e às possibilidades de acesso aos documentos $^{7}$ ainda hoje são objeto de controvérsia entre membros do governo e militares, especialmente aqueles que dizem respeito à Guerrilha do Araguaia e à Operação Condor. Um passo importante foi dado com a publicação, em 29 de agosto de 2007, do livro Direito à memória e à verdade, resultado de 11 anos de trabalho da Comissão Especial sobre Mortos e Desaparecidos Políticos, primeiro documento oficial do governo federal a responsabilizar a ditadura militar pela tortura e morte de vários de seus opositores. A publicação causou um profundo mal-estar no Alto Comando do Exército, que reagiu negativamente ao lançamento do livro. Ou seja, a batalha ainda não foi encerrada e os fantasmas continuam pairando entre lembranças e esquecimentos.

\section{VI}

É importante, por fim, refletir sobre o papel dos historiadores nessa contenda. Afinal, suas habilidades profissionais foram muitas vezes lembradas e requisitadas nos discursos de memória reproduzidos ao longo deste artigo.

Do ponto de vista acadêmico, percebe-se, nos últimos anos, uma proliferação das pesquisas históricas sobre a ditadura. ${ }^{8} E$ interessante observar que as primeiras investigações sobre a luta armada no Brasil são de autoria de dois militantes de esquerda que combateram o regime militar: Combate nas trevas, de Jacob Gorender (1987), e A revolução faltou ao encontro, de Daniel Aarão Reis Filho (1990). Nestas obras, misturam-se a testemunha e o historiador, o que viu e o que deve desconfiar do que viu. Ambos, Gorender e Reis Filho, buscam por caminhos diferentes explicar a derrota da esquerda diante dos militares, ou seja, ao mesmo tempo tentam compreender um processo histórico e "acertar contas"

Anos 90, Porto Alegre, v. 14, n. 26, p.127-156, dez. 2007 
consigo mesmos e com seus companheiros de luta. Só em 1993 tem-se a publicação do livro $O$ fantasma da revolução brasileira, de Marcelo Ridenti, o primeiro pesquisador da luta armada que não foi militante político (ROLLEMBERG, 2003). Desde então, historiadores de gerações mais recentes vêm se dedicando ao estudo do período sob os mais variados pontos de vista e com o uso de fontes diversificadas, com ênfase na história oral.

Contudo, para além dos círculos universitários pode-se dizer que, em 2004, os historiadores não foram os protagonistas do debate público sobre a ditadura. Um exemplo: a obra mais comentada naquela ocasião a respeito do tema é de autoria de um jornalista, Elio Gaspari. Este autor teve acesso a documentos e entrevistas inéditos que lhe permitiram elaborar uma narrativa minuciosa dos acontecimentos da época, com destaque para a trajetória de dois personagens: o ex-presidente general Ernesto Geisel e o coronel Golbery do Couto e Silva, uma das "eminências pardas" do regime. Logo no início do primeiro volume, porém, Gaspari advertiu: "Em nenhum momento passou pela minha cabeça escrever uma história da ditadura. Falta ao trabalho a abrangência que o assunto exige [...]" (GASPARI, 2002, p. 20). Porém, sua obra atingiu grande repercussão na mídia e tornou-se um best-seller, apesar das críticas mais ou menos ferozes dos historiadores (FICO, 2004 e MAESTRI e JAKOBSKIND, 2003). Em um artigo da imprensa, chegou-se a afirmar: "depois da obra de Elio Gaspari os historiadores terão de reinventar seus estilos e cuidados" (apud FICO, 2004, p. 55). Neste caso, valeria a pena retomar a questão colocada por Hartog e Revel (2001, p. 21) relativa à historiografia francesa: “[...] qual papel ou que divisão de papéis [existe] entre um [o historiador] e outro [o jornalista], sabendo que as temporalidades respectivas nas quais eles trabalham não são as mesmas?".

Como foi ressaltado anteriormente, segundo as declarações do presidente Lula, do ex-ministro Viegas e de algumas lideranças 
Cicatriz aberta ou página virada? Lembrar e esquecer o golpe...

militares, caberia aos historiadores a tarefa de fixar o "justo lugar" - ou o "lugar verdadeiro" - dos fatos passados através da escrita da história. Em relação ao regime militar, especificamente, este deveria ser imobilizado nos livros, de preferência como uma "página virada", desvinculada do contexto atual do Brasil, no qual, ainda de acordo com tais personagens, a sociedade estaria reconciliada e a democracia consolidada.

No que tange às vítimas e familiares, os inquestionáveis traumatismos pelos quais passaram parecem conferir, por si sós, o estatuto de prova às suas narrativas: o ter visto e, mais ainda, o ter sentido "na pele" os sofrimentos imputados pelos agentes da repressão, os autoriza, aparentemente, a assumir a função de reescrever a história recente do país.

Diante de tais posturas, pode-se levantar algumas reflexões que parecem se adequar perfeitamente ao tema deste artigo. A primeira, já clássica, de autoria de Marc Bloch (1998, p. 60-61), lembra os historiadores do erro de se considerar o presente "autointeligível", pois isso seria supor "[...] que as condições humanas passaram, no intervalo de uma ou duas gerações, por uma transformação não apenas muito rápida mas também total [...]. Isso significa esquecer a força da inércia própria a tantas criações sociais". A segunda, bem mais recente, refere-se ao papel do testemunho. A esse respeito, Hartog e Revel (2001, p. 21) perguntam: "A testemunha é uma 'fonte' ou uma 'voz' que é melhor conhecer on line, sem passar pela 'mediação' do historiador?’. Uma possível resposta encontra-se em outro texto de Hartog (1998, p. 8): "O historiador não começa a ser historiador a não ser procurando se separar do testemunho [...] com todos os problemas epistemológicos que esta operação coloca".

O debate sobre esses problemas epistemológicos - e éticos, acrescento eu - talvez auxilie os historiadores a encontrarem uma posição mais "justa" na batalha de memórias relativa à ditadura militar brasileira.

Anos 90, Porto Alegre, v. 14, n. 26, p.127-156, dez. 2007 


\section{Benito Bisso Schmidt}

\section{Open wound or turned page? Recall and forget the 1964 coup d'état forty years later}

Abstract: In 2004, the $40^{\text {th }}$ anniversary of the coup d'état which started civil-military dictatorship in Brazil gave place in public field to many conflicting memory discourses dealing with this subject, especially to discourses of the government, military leaders, victims and their families. This essay intends to place this conflict in the global context of a "memory culture"; then, it analyses the backings, agents, reasons and images particular to each one of these discourses, as well as their fitting and silencing strategies of memories of that time. Finally this article discusses the role taken by historians in this "battle of memories".

Keywords: Memory. Civil-military Dictatorship. Present time

\section{Notas:}

${ }^{1}$ Uma primeira versão deste texto foi apresentada, em fevereiro de 2005, como conferência no seminário "Les usages politiques du passé", dirigido pelos professores Sabina Loriga e Jacques Revel na École des Hautes Études en Sciences Sociales (EHESS). A eles agradeço pelo convite e pelos comentários. Agradeço também à historiadora Caroline Bauer pelas informações sobre os arquivos repressivos. Versões anteriores foram publicadas como: Années de plomb: la bataille des mémoires sur la dictature civile-militaire au Brésil. Cabiers d'Histoire. Revue d'Histoire critique, n. 99, avril-juin 2006 e Brasile '64. Memorie in conflitto nelle narrazioni del colpo di Stato militare. 900. Per uma storia del tempo presente, n. 14-15, gennaio-dicembre 2006.

${ }^{2}$ Sobre as noções de enquadramento e de silenciamento da memória, ver POLLAK (1989) e ROUSSO (1985).

${ }^{3}$ Algo semelhante parece estar ocorrendo hoje em relação às comemorações dos 200 anos da chegada da família real portuguesa ao Brasil.

${ }^{4}$ A respeito deste tema, consultar, entre outros: CARDOSO, 1994; FICO, 2004 e MARTINS FILHO, 2002.

${ }^{5}$ Recentemente, o ministro da Secretaria Especial dos Direitos Humanos, Paulo Vannuchi, propôs a revisão da lei da anistia, o que provocou a reação de comandantes militares. O general da reserva Francisco Batista Torres de Melo, coordenador do Guararapes, grupo de ex-oficiais do Exército, Marinha e Aeronáutica, declarou: "Os militares não foram anistiados. Estávamos defendendo a sociedade, que estava sendo destruída. Eles achavam que eram os donos da verdade e foram anistiados porque nós queríamos que no Brasil os irmãos se abraçassem" (ZERO HORA, 29/12/2007, p. 6).

Anos 90, Porto Alegre, v. 14, n. 26, p.127-156, dez. 2007 
Cicatriz aberta ou página virada? Lembrar e esquecer o golpe...

${ }^{6}$ Por exemplo: enquanto a ministra Dilma Rousseff, da Casa Civil, defende o fim do chamado sigilo eterno, Celso Amorim, das Relações Exteriores, busca preservar este dispositivo, visando manter inacessíveis ao público os documentos relativos à Guerra do Paraguai, os quais, segundo alguns diplomatas, poderiam provocar crises diplomáticas. "Como Lula deseja tomar uma decisão para acesso a documentos oficiais de todos os períodos históricos do Brasil, o veto de Amorim emperra uma saída e, por tabela, a divulgação de arquivos da ditadura de 1964" (FOLHA ONLINE, 19/03/2008).

${ }^{7}$ Em princípio, apenas os diretamente interessados nos documentos já liberados, ou seja, aqueles que têm o seu nome ou de cônjuge, ascendentes ou descendentes neles citados, podem consultar os arquivos. Pesquisadores devem pedir a autorização das pessoas mencionadas nos documentos.

${ }^{8}$ Para um balanço desses estudos, ver: FICO, 2004 e RIDENTI, 2001. Mas basta uma olhada nas listas das editoras e das dissertações e teses defendidas nos programas de pós-graduação do país para verificar que o número de trabalhos sobre a ditadura civil-militar é cada vez maior.

\section{Referências:}

BIZ, Osvaldo (org). Sessenta e quatro: para não esquecer. Porto Alegre: Literalis, 2004. BLOCH, Marc. Apologie pour l'histoire ou Métier d'historien. Paris: Armand Colin, 1997.

BRASIL. Lei n. 9.140 de 4 de dezembro de 1995. Reconhece como mortas as pessoas desaparecidas em razão de participação, ou acusação de participação, em atividades políticas, no período de 2 de setembro de 1961 a 15 de agosto de 1979, e dá outras providências. Diário Oficial da União, Brasilia, 05/12/1995. p. 1985, col. 1. 1995.

BRASIL. Secretaria Especial dos Direitos Humanos. Comissão Especial sobre Mortos e Desaparecidos Políticos. Direito à memória e à verdade. Brasília: Secretaria Especial dos Direitos Humanos, 2007.

CARDOSO, Lucileide Costa. Construindo a memória do regime de 64. Revista Brasileira de História-Brasil, 1954-1964. São Paulo, ANPUH-Marco Zero, v. 14, n. 27, 1994.

CARTA CAPITAL, Ano XI, n. 308, 15 de setembro de 2004.

COIMBRA, Cecília. A caixa preta da ditadura. Caros Amigos, Ano VIII, n. 92, novembro de 2004.

CORREIO DO POVO. Porto Alegre. jan-dez 2004.

FICO, Carlos. Além do golpe: versões e controvérsias sobre 1964 e a ditadura militar. Rio de Janeiro: Record, 2004.

Anos 90, Porto Alegre, v. 14, n. 26, p.127-156, dez. 2007 


\section{Benito Bisso Schmidt}

FOLHA DE SÃO PAULO. São Paulo. jan-dez 2004.

FOLHA ONLINE. São Paulo. jan-dez 2004. Disponível em: < http:// www.folha.uol.com.br/>. Acesso em 03/2008. Acesso em 03/2008.

GASPARI, Elio. A ditadura envergonhada. São Paulo: Companhia das Letras, 2002.

GOMES, Ângela de Castro. Escrita de si, escrita da História: a título de prólogo. In: __ (org.). Escrita de si, escrita da História. Rio de Janeiro: FGV, 2004.

HARTOG, François et REVEL, Jacques. Note de conjoncture historiographique. In:___ (sous la direction de). Les usagespolitiques du passé. Paris: Édition de l'EHESS, 2001.

HARTOG, François. L'historien et la conjoncture historiographique. Le Débat, histoire, politique, société, n. 102, novembre-décembre 1998.

. O tempo desorientado. Tempo e História. "Como escrever a história da França?”. Anos 90, PPG em História da UFRGS, n. 7, julho 1997.

HUYSSEN, Andreas. Seduzidos pela memória: arquitetura, monumentos, mídia. Rio de Janeiro: Aeroplano, 2000.

INFORMEX. A palavra oficial do exército, n. 11, 25/03/2004. Disponível em: $<$ http://www.exercito.gov.br/05Notici/Informex/2004/infor011.htm>. Acesso em 09/01/2005.

LISBOA, Nei. Relativizando o injustificável. In: BIZ, Osvaldo (org). Sessenta e quatro: para não esquecer. Porto Alegre: Literalis, 2004a.

LISBOA, Suzana. Seria chover no molhado, se o molhado não fosse sangue... In: BIZ, Osvaldo (org). Sessenta e quatro: para não esquecer. Porto Alegre: Literalis, 2004b.

MAESTRI, Mário e JAKOBSKIND, Mário Augusto. As ilusões armadas. A historiografia envergonhada. Observatório da Imprensa. Matérias-14/05/2003. Disponível em: <http://observatorio.ultimosegundo.ig.com.br/artigos/al140520032.htm>. Acesso em 06/01/2005.

MARTINS FILHO, João Roberto. A guerra da memória. A ditadura militar nos depoimentos de militantes e militares. Varia História, UFMG, n 28, dezembro 2002. NORA, Pierre. La loi de la mémoire. Le Débat, histoire, politique, société, $\mathrm{n} \cdot 78$, janvierfévrier 1994.

O SUL. Porto Alegre. out-dez 2004.

POLLAK, Michel. Memória, esquecimento, silêncio. Estudos Históricos, CPDOC/ FGV, n. 3, 1989.

PROST, Antoine. Como a história faz o historiador? Anos 90. PPG em História da UFRGS, n. 14, dezembro de 2000

Anos 90, Porto Alegre, v. 14, n. 26, p.127-156, dez. 2007 
Cicatriz aberta ou página virada? Lembrar e esquecer o golpe...

REIS, Daniel Aarão. Ditadura militar, esquerdas e sociedade. Rio de Janeiro: Zahar, 2000.

REVEL, Jacques; DE CERTEAU, Michel e JULIA, Dominique. A beleza do morto: o conceito de "cultura popular". In: REVEL, Jacques. A invenção da sociedade. Lisboa/ Rio de Janeiro: Difel/Bertrand Brasil, 1989.

RICOEUR, Paul. La mémoire, l'histoire, l'oubli. Paris: Seuil, 2000.

RIDENTI, Marcelo. As esquerdas em armas contra a ditadura (1964-1974): uma bibliografia. Cadernos AEL - Tempos de ditadura: do golpe de 1964 aos anos 1970. Campinas: UNICAMP/Arquivo Edgard Leuenroth, v. 8, ns.14/15, primeiro e segundo semestres de 2001.

ROLLEMBERG, Denise. Esquerdas revolucionárias e luta armada. In: FERREIRA, Jorge e DELGADO, Lucilia de Almeida Neves (orgs.). O tempo da ditadura: regime militar e movimentos sociais em fins do século XX. Rio de Janeiro: Civilização Brasileira, 2003.

ROUSSO, Henry. Vichy, le grand fossé. Vingtième Siècle. Revue d'histoire, 5, 1985.

TAVARES, Flávio. Memórias do esquecimento. São Paulo: Globo, 1999.

VALENSI, Lucette. Histoire nationale, histoire monumentale. Les lieux de mémoire (note critique). Annales HSS, n. 6, novembre-décembre 1995.

ZERO HORA. Porto Alegre. out-dez 2004.

Recebido em 08/02/2008.

Aprovado em 07/03/2008.

Anos 90, Porto Alegre, v. 14, n. 26, p.127-156, dez. 2007 